Article

\title{
Conjugation of the Belt and Road Initiative and Eurasian Economic Union: Problems and Development Prospects
}

\author{
Elnur Mekhdiev ${ }^{1, *(D)}$, Irina Pashkovskaya ${ }^{2}$, Elena Takmakova ${ }^{3}$, Olga Smirnova $^{4}$, \\ Khadiya Sadykova ${ }^{5}$ and Svetlana Poltorykhina ${ }^{6}$ \\ 1 Center for Analysis, Risk Management and Internal Control in Digital Space, Financial University under the \\ Government of the Russian Federation, Moscow 125993, Russia \\ 2 Euro-Atlantic Security Center, Moscow State Institute of International Relations (MGIMO), Moscow 119454, \\ Russia; irina-pashkovskaya@bk.ru \\ 3 Department of Innovation and Applied Economics, Orel State University, Orel 302026, Russia; \\ takmakova-elena65@mail.ru \\ 4 Department of Philosophy and Socio-Political Technologies, Gubkin Russian State University of Oil and \\ Gas (National Research University), Moscow 119991, Russia; olga-smirnova77@bk.ru \\ 5 Department of Economics and Production Management, Tyumen Industrial University, Tyumen 625000, \\ Russia; khadiya.sadykova@bk.ru \\ 6 Department of Finance and Credit, Kazan Innovative University named after V.G.Timiryasov (IEML), \\ Kazan 420111, Russia; poltorykhina.s@list.ru \\ * Correspondence: e.mehdiev@gmail.com
}

Received: 12 May 2019; Accepted: 2 December 2019; Published: 5 December 2019

\begin{abstract}
The study addresses the problems arising in association with the conjugation of the Eurasian Economic Union (EAEU) and the Belt and Road initiative. The hypothesis is that the conjugation is economically effective, and this is proven by the statistical analysis of trade and investment dynamics and buttressed by empirical observations. Based on this, the recommendations for the EAEU are given. The paper dismantles the problems arising in the sphere of security and peacekeeping and proposes a number of steps for ensuring peace and stable development in the region, implementing the Shanghai Cooperation Organization (SCO) mechanism. The article highlights the main plans of the China-EAEU partnership and puts forward alternative cooperation strategies for the People's Republic of China (PRC). The authors develop the most attractive plan for the EAEU and propose the best strategy for its implementation.
\end{abstract}

Keywords: integration; Eurasian Economic Union; One Belt One Road

JEL Classification: F02; R10; F15; L90

\section{Introduction}

The Chinese Belt and Road initiative (today known as the Belt and Road Initiative (BRI), although its previous conception, One Belt One Road, in the authors' opinion, was much more accurate from the point of view of cultural and socioeconomic conjugation) is the key point of Xi Jinping's foreign political policy. Alongside the expansion of the People's Republic of China (PRC), Russia is in search of new drivers to buttress its power in the region of the former USSR and Central Asia. The integration of new economies into the project of the Eurasian Economic Union (EAEU) and its gain in terms of global influence is the central goal of Russian foreign policy in Central Asia. It pursues not only the proliferation of Russian economic influence but balances the Chinese pursuit of becoming a superpower in Eurasia, particularly in South-East and Central Asia. 
Still, there are a number of obstacles to this ever-widening partnership. China, in 2019, shifted abruptly to the new concept of the Belt and Road initiative-from the major focus on the logistics potential to the investment cooperation development for the reasons described hereinafter-and the second BRI Summit offered many issues for discussion. The EAEU is entering a difficult period of preserving trade borders and building up tensions between participants due to different visions of future integration. Moreover, Russia, Kazakhstan and Belarus, forming a core of this integration, breed discrepancies in their strategies of developing economic partnership inside the EAEU instead of trying to overcome them. The rationale for this problem arises from the challenging economic situation in Russia, which was one of the main donors of financial resources in the developing EAEU. In addition, despite demonstrating magnanimity to its partners, Russia does not follow (or, more accurately, cannot afford to follow) the Soviet practice of giving out subsidies to friendly countries without receiving support and preferences in return.

Other constraints regarding ways to conjugate the EAEU and BRI lie in the sphere of logistics, trade barriers, political tensions and fears of strong partners, intrinsic to post-Soviet and less developed countries.

The increase in the number of conflicts close to the Russian borders in the last decade, the economic war unleashed by the pro-American countries against China, tensions around India, Afghanistan and Pakistan signal that the unipolar system of international relations is striving to survive, and therefore, blocks the actions of its main rivals. All in all, global discrepancies force developing countries to fight for their interests and lead to earlier unimaginable unions. From this point of view, realizing Putin's idea of "Big Eurasia" serves not only Russian interests, but provides a basis for safe and secure regional cooperation. China follows the same goals, but for other reasons, so a systematic approach to coordinating actions and dividing spheres of interests, or rather, obtaining a consensus regarding the path by players of the new "Great Game", is crucial. Conjugation of the EAEU and BRI can provide a solution to this problem. The article pursues the goal of proving that the conjugation of the Russian and Chinese initiatives in the sphere of geopolitical and socioeconomic development is useful to both countries and consequently, their satellites. The authors focus on the economic and financial aspects of the conjugation process, but due to the important role politics plays in the process of formation of the EAEU and the cultural, political and social matters that BRI incorporates, the study tends to unite these issues in one general path of discussion.

\section{Literature Review}

The problem of the conjugation of the EAEU and BRI is the subject of considerable debate at many economic and political events, as are the foreign policies of Russia and China. The most respected Russian experts Glazyev (2017) and Luzyanin (2016a, 2016b) have devoted a number of articles to the problem of the future of Eurasian integration.

Chinese experts were the first to develop the concept of strategic cooperation between China and other countries of the Silk Road Economic Belt (the predecessor of BRI) (Chzhao 2015; Li 2016; Mingfu 2015; Lim et al. 2016; Wang 2016; Weiwei 2016), but the idea of conjugation with the EAEU was not one of the key themes of their works until recently. All of them stressed the peaceful and constructive character of the BRI and highlighted the idea of China carrying out the new global power conception. According to Cheng Li (2016), who, it seems, repeated the motto of Xi Jinping-when China achieves global leadership, it will not repeat the mistakes of contemporary hegemons, it will seek compromise and will not implement harsh measures and send military forces to other countries. The main reason for such behavior lies in "the peaceful nature of Chinese culture" (Campbell and Ratner 2018). Still, this statement is doubtful, especially taking into account recent actions that China undertook in the South Chinese Sea and in Vietnam.

The Western experts have a negative view on China gaining power, pinpointing the risks that the BRI brings to the European Union and national economies (Djankov and Miner 2016; Stronski and Ng 2018; Parello-Plesner and Duchâtel 2015; Miller 2017). At the same time, Kissinger (2012), in his world-famous 
work "On China", proves that China cannot be a "mild" superpower due to its culture and political and economic course.

Many of the mentioned works (especially of European and American scientists) do not mention the EAEU because it is either considered a matter of no importance or because the influence of this organization on the global arena is not sustainable. In this context, the works by Vinokurov and Tsukarev (2018), Zank (2017) and Czerewacz-Filipowicz (2017) provide a thorough economic study of the effects and the prospects of EAEU in the vast field of possible strategies of its development.

This paper offers a new approach to the problem. Trilateral talks between Russia, India and China (RIC format) under the brand of the Shanghai Cooperation Organization (SCO) are a mighty instrument for resolving problems in the region. These are the most powerful players of the Asian region and they possess the power of making changes to the future of Asia. Their cooperation, which can be achieved by dialog, is the key to realizing improvements in the region, but for now, every participant in the dialog, except India, propels its mechanisms in the regions of South-East and Central Asia. Hence, the tensions about the currency of contracts and the monetary risks rise, in addition to that, the foreign direct investment (FDI) flows are made more politically dependent, leading to transactional costs of interactions in the region are unreasonably high, mostly because of different financial systems (Wink et al. 2011). India, in turn, aspires to achieve domination in Southern Asia, competing with China's clout in the region. The issue of the competition of these powers in Central Asia is not mentioned intently, because it is impossible to cover this issue too in the article. Resolving these issues is a key task of the conjugation initiative, as without Indian influence on the process, the conjugation of the two non-equal institutions will lead to the loss of balance in the region and will negatively affect the Russian power in Asia. Consequently, China will lose its major partner (EAEU) in Asia, gaining weak and non-willing inferior countries with a burden of problems to solve and ambitions of regional leadership broken (Russia and Kazakhstan especially) (Garbuzarova 2019).

\section{Methodology}

The paper provides a comparative analysis of statistical data on international trade in the region. The hypothesis of the following model is that conjugation of the EAEU and BRI will provide a synergetic effect to all of the participants. In order to prove that: (a) the EAEU should provide synergetic effects to its participants, or, at least, not slow down their development; (b) the BRI should be an effective investment mechanism, attracting not only Chinese but Asian capital in general; (c) partnership between countries and the conjugation process should be transparent and provide equal opportunities (or at least not discriminating conditions) to all members.

The first statement is to be tested by comparing trade growth between EAEU members and trade growth between EAEU countries and all the other states. If the data in the first row are higher than in the other five, the EAEU is effective despite problems and a massive bundle of trade barriers and exceptions. The method arises from the fact that the EAEU was born from a trade union and, up to now, its main effects lie in the sphere of trade liberalization and the stimulation of exports. The effectiveness in this context is the most appropriate term, as the EAEU, on this stage, serves to stimulate trade and thereby provide numerous economic benefits to its members.

The second statement can be tested by analyzing foreign direct investment (FDI) inflows in the chosen countries (those participating in the BRI except China, India and Russia because they are supposed to be net exporters of capital in the project) and comparing their dynamics with the previous data. If FDI inflows grow faster than they did before, this indicates the growth in the number of infrastructure and energy projects especially, and the BRI may be considered as an effective investment mechanism. This result may occur due to the overall better growth rates of the BRI countries, and in order to verify the results, it is reasonable to provide a short analysis of investment projects under the BRI. For this purpose, the authors have conducted an analysis of the Asian Infrastructure Investment Bank (AIIB), the main development bank supporting and attracting FDI to the BRI projects. If the volume of investments of the AIIB steadily grows, on a higher pace, than the overall GDP growth 
in South-East Asia, the significant share of the FDI attracted by the BRI result from the BRI and its institutions' activity. The analysis of FDI inflows allows for estimation of whether the named countries are attractive to the investors, and the more attractive the country is to the investors, the more comparative advantages it has (Porter 1990a, 1990b). If the FDI inflows grow, the attractiveness grows too, and taking the conservative strategies of the chosen countries in the sphere of economic policy into account, the main contribution to this growth is given by the BRI.

The third statement can only be tested empirically, on the basis of open data on common projects realized under the brand of BRI in different countries, particularly those aimed at developing maritime infrastructure along the Maritime Silk Road Belt (MSRB).

After analyzing every part of the hypothesis, it will be possible to make a conclusion about the economic effectiveness of the conjugation-whether it has positive or negative economic effects or is just politically important for current leaders such as V. Putin, Xi Jinping, N. Nazarbaev (as the "thought leaders" of the conjugation project) and Ram Nath Kovind (as one of the leaders whose country benefits the most).

\section{Results}

\subsection{EAEU Effectiveness}

As follows from Table 1, the average trade growth rate is generally lower than the intra-EAEU trade growth rate, although it is notable that in 10 months of 2018 it was significantly higher. Such dynamics of the parameter indicate that 2018 was the worst year for the EAEU since it was established. Failing to overcome the obstacles (officially, there are 73 of them (EEC Portal 2019); however, various sources refer to more than 200 of them in reality (Wolczuk and Dragneva 2017)), the sanctions imposed against Russia and the lasting stagnation of integration are extinguishing the stimulus effects that the EAEU provides to its members.

Table 1. Trade growth rates in the Eurasian Economic Union (EAEU).

\begin{tabular}{ccccccc}
\hline Year & $\mathbf{2 0 1 3}$ & $\mathbf{2 0 1 4}$ & $\mathbf{2 0 1 5}$ & $\mathbf{2 0 1 6}$ & $\mathbf{2 0 1 7}$ & $\begin{array}{c}\mathbf{2 0 1 8} \\
\text { (Jan-Oct) }\end{array}$ \\
\hline Intra-EAEU trade & 95.1 & 90.7 & 74.6 & 94.2 & 127.4 & 111.1 \\
Russia & 100.8 & 93.1 & 66.5 & 88.8 & 124.6 & 120.9 \\
Kazakhstan & 100.0 & 91.6 & 61.0 & 80.3 & 124.8 & 127.2 \\
Belarus & 82.9 & 96.7 & 75.4 & 84.9 & 123.5 & 121.0 \\
Armenia & & & 76.5 & 103.3 & 124.9 & 122.5 \\
Kyrgyz Republic & 94.6 & 93.8 & 70.5 & 93.6 & 121.6 & 121.06 \\
Average rate & \multicolumn{5}{c}{98.85} \\
Average rate 2013-2017 & \multicolumn{7}{c}{} \\
Source: Created by authors, based on statistics of the Eurasian Economic Commission (EEC 2019).
\end{tabular}

The analysis of the data in Table 1 indicates that the economic effect of the EAEU is overestimated, but the results suit the criterion above. To compare the economic effect of the EAEU we have counted the average growth of intra-EU trade from 2013 to 2017 based on Eurostat (2019) data and obtained a result of a 1.0342 growth rate in the EU compared to a 0.9885 growth rate in the EAEU. The EAEU does not slow the development of member countries and has a positive effect on their economies. The EU was chosen because it is commonly referred to as one of the examples of successful regional integration and monetary union, and because it pursues the same goals (creating a single currency, deeper integration and common development strategies).

The geopolitical and consequently geoeconomical situation around Russia makes it vital for it to build a strong system of relations with emerging powers such as China and India. In order to gain more than lose, the Russian Federation must create a reliable deterrence mechanism that will serve to protect its economic system from external influence and pressure. It cannot hold out alone, so the EAEU 
and the countries joining it or at least conducting the same policy seem to be the ideal counterforce for Chinese expansion. This is the other element of EAEU effectiveness, but it is undermined by the Kazakh ambitions and enticing prospects of close cooperation with China (compared with an uncertain future of financial partnership with Russia).

When speaking about FDI flows in the EAEU, the Union is to be considered moderately effective for all its members, still Russia serves as the main investor, providing high risks for the Union (the same situation is for BRI-China is the main investor, while other countries are recipients of the FDI, still in BRI the situation is being balanced by the significant FDI flows in South-East Asia, generated by the countries of the region and by India, which exports FDI, leading to the better balance of risks) (Table 2).

Table 2. Foreign direct investment (FDI) balance in the Eurasian Economic Union (EAEU) (billion US dollars).

\begin{tabular}{cccccc}
\hline Investor Country (Row) & Armenia & Belarus & Kazakhstan & Kyrgyzstan & Russia \\
\hline Armenia & & 0 & 0 & 0 & 57.7 \\
Belarus & 1.6 & & 2 & -0.4 & 468 \\
Kazakhstan & 0.1 & -0.7 & & 1.3 & 466.7 \\
Kyrgyzstan & 0 & 0.1 & -26.1 & & 14.4 \\
Russia & 15 & 8.1 & 73.7 & -14.2 & \\
\hline
\end{tabular}

Source: Created by authors, based on Eurasian Development Bank 2019.

Table 2 allows us to conclude that the investment mechanisms of the EAEU are aimed at promoting the Russian economic institutions in the Union, in this way reminding of the Chinese vision of the BRI development (Johnston 2019).

\subsection{Investment Effectiveness Estimation in the BRI}

As is shown in Figure 1, only a couple of countries of the initiative enjoy stable FDI inflow growth. Vietnam, Korea, Indonesia and, to a lesser extent, Myanmar and Greece have growing FDI inflow growth. It is noteworthy that these countries have agreed to a number of Chinese projects (except for Korea, which chose to have closer relations with Washington than Beijing) and some of them are close allies of the PRC.

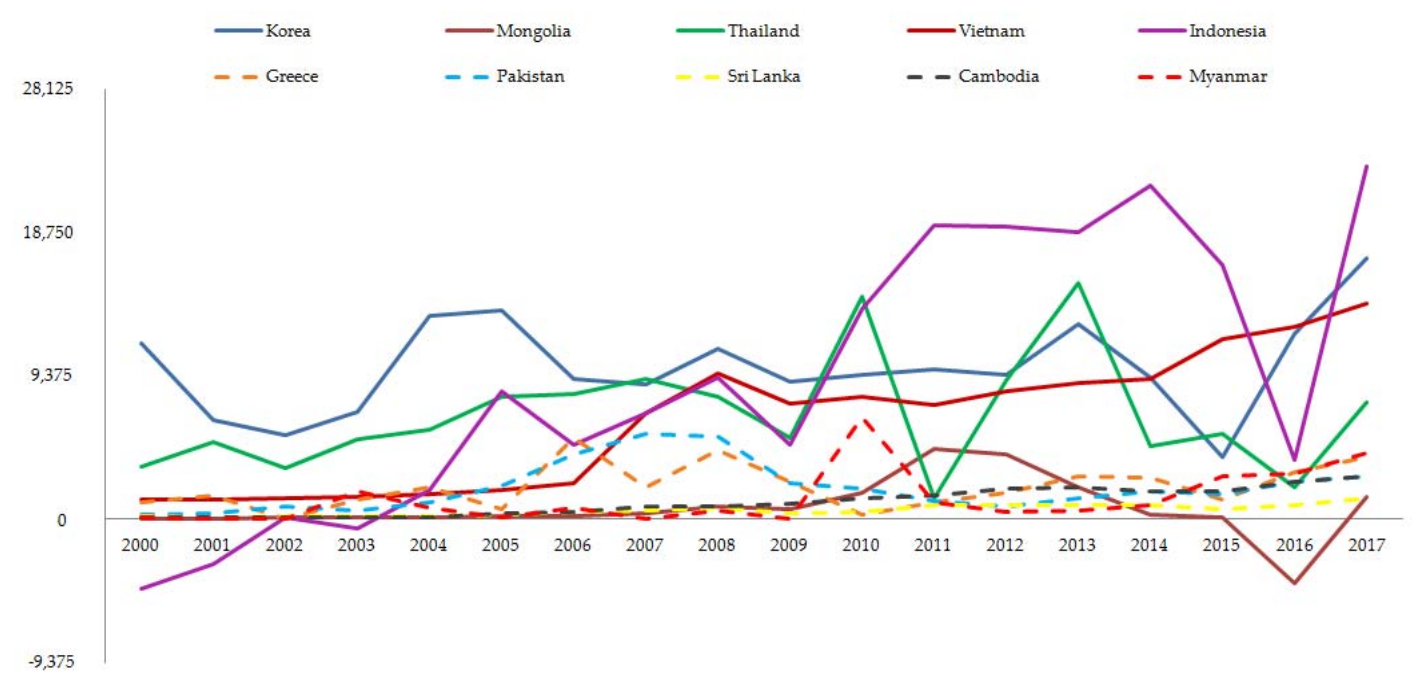

Figure 1. Foreign direct investment (FDI) inflows in the chosen countries. Source: Created by authors, based on the statistics of the United Nations Conference on Trade and Development (UNCTADstat 2019).

The effect of FDI on the economy of a country is hard to overestimate. It is vitally important for developing and less developed economies, striving to create a 21st century economy on the basis of the existing one (Ansar et al. 2016). The BRI is a salvation for these countries because it offers a way 
out-the main goal of the project is to create a modern infrastructure to transport goods and services via the main corridors that lie in Central Asia, South-East Asia, the Middle East, the former USSR and, if taking into account the MSRB, Eastern Africa. These regions are flooded by economic and social problems, such as poor education, bad medical services, high unemployment, terrorist threats and high crime rates. In general, the roots of all these disastrous problems lie in the bad economy and poverty. The first step to overcome them is offered by the BRI-namely, creating a modern infrastructure and offering workplaces to service it (Zhou 2018). Moreover, the BRI faces security problems, for instance, the Korean Peninsula nuclear problem, Afghanistan terrorism threat spreading in Central Asia, drug routes from Asian suppliers to European consumers, etc. Overcoming them and providing security in the region can be reached by cooperation in the sphere of security and peacekeeping in Asia with the SCO. This track of BRI development leads to tighter relations between regional powers - the PRC, Russia and India (all of them being members of the SCO) - providing a wider field for the conjugation of Russian and Chinese projects of regional development (the BRI and "Big Eurasia", the physical representation of the latter is the EAEU).

In order to assess whether this effect is achieved due to the countries' activity under BRI or other exogenous factors, we address the AIIB statistics in Table 3.

Table 3. The Asian Infrastructure Investment Bank (AIIB) activity indicators.

\begin{tabular}{cccc}
\hline Indicator & $\mathbf{2 0 1 6}$ & $\mathbf{2 0 1 7}$ & $\mathbf{2 0 1 8}$ \\
\hline Investments (billion \$US) & 1.69 & 4.22 & 7.5 \\
Private capital mobilized (billion \$US) & 0.05 & 0.57 & 0.72 \\
Projects developed & 8 & 23 & 35 \\
\hline Source: Created by authors, based on AIIB 2019.
\end{tabular}

Table 3 demonstrates an average growth in overall investments for the period of $108 \%$, meaning that in the past two years the volume of investments of the AIIB doubled each year. The rate of growth is much higher than the average GDP growth in South-East Asia of 6.5\% (OECD 2018), meaning that the hypothesis of the BRI economic effectiveness for its members is true.

All the roads of the BRI cross the regions where there are different threats. These are drug dealing and terrorism (to a lesser extent) in Central Asia, terrorism and high crime rates in South Asia, Afghanistan, Pakistan and Indonesia and piracy along the Western coast of Africa. These threats are damaging to the transportation of goods, capital flows and migration of human capital along the BRI corridors. Moreover, they tend to spread. In addition to building closer partnership relations with the EAEU, this idea allows China to promote the idea of safety and peacefulness regarding its expansion. At the same time, Russia has a rich experience of settling regional conflicts and fighting terrorism (for example, Chechnya in 1990s, Ossetia in 2008, Syria and many other situations, when terrorism was successfully fought on Russian territory). This experience can help develop a new system to pre-empt threats in Asia and reform the SCO.

At the same time, SCO financial mechanisms, which are today under construction, namely the SCO Bank, the Special Account of SCO and the SCO Banking Union, may contribute to the formation of a better financial environment and to a conjugation of better-quality institutions of the EAEU and the BRI.

\subsection{Transparency of Conjugation}

The process of conjugation in modern conditions is propelled by the Chinese will to find new markets and reliable partners and EAEU members seeking financial resources and alternative partners because of anti-Russian sanctions. The aims of the participant are clear, but the mechanisms are still obscure.

The Chinese vision of the initiative still gives a wide field for speculation. The initial concept was that the project would include a number of so-called corridors between China and Eastern Europe. This vision 
allowed the EAEU to benefit from the transfer of goods more than any other organization. It changed with time, including the introduction of the MSRB, creating a vast infrastructure of loosely connected investment projects. Today, the initiative looks like an endeavor to create a unified infrastructure in some countries, introducing Chinese-like railroads and product standards (Belt and Road Portal 2018) and a network of trade and cooperation agreements with initiative-participating states (Xinhua 2013, 2017; MFA of the People's Republic of China 2017a, 2017b). This approach does not offer such advantages to the EAEU, and they are mostly exposed through the reduction of transactional costs. The largest part of these costs is to be reduced by cutting down costs of interactions between residents of participating countries; however, this effect is far smaller than it was planned before the paradigm change.

Such radical deviation from the course of the first years makes the process of joining the initiative risky from the point of view of indecisive leaders. Still, despite the fact that conjugation of the EAEU and BRI is a necessary step for further development of the EAEU and can provide preferences for logistics of goods from China (the infrastructure of the EAEU countries is better than in Central Asia and is no worse than in South-East Asia), Xi Jinping tries to realize the dream of global Chinese dominance through spreading the influence of the PRC in less developed countries and exploiting their resources.

Today, there are more than 30 ports with Chinese engagement, some of which are far from the main routes of the MSRB, and the network of Chinese investment spreads quickly and overgrows the BRI. This tendency causes concern among other countries, including Russia. In addition, China is encouraging its companies to invest abroad. Chinese officials have issued a list of 11 countries they unofficially recommend to invest in (Russia included) and a white paper of sensitive sectors for foreign investment (Xinhua 2018a). Among the most ambitious projects with Chinese affiliation are the construction of a power plant in Lao (China Development Bank issued a credit of \$770 million) and a number of projects in Mozambique that obtained overall financing of $\$ 5$ billion. Moreover, the results of 2017 are impressive-China Development Bank issued more than $\$ 180$ billion for the development of BRI projects (Xinhua 2018b), moreover, foreign financial corporations joined the project, for instance, the Standard Chartered Group promised to issue a $\$ 20$ billion or more credit for the initiative development (Zhang 2017). All in all, these tendencies demonstrate the overwhelming financial power of China and result in deep concerns of the EAEU authorities that see the future of conjugation as uncertain. According to their opinion, conjugation can lead to Chinese expansion and economic dependency from the PRC.

Regretfully, it is a logical development of the initiative, but except for establishing Chinese economic leadership in less developed countries, it brings them many benefits. Constructing a road from Jakarta to Bandung in Indonesia, a high-speed railroad from China to Lao (as part of Chinese high-speed railroad diplomacy and a signal of its successes), active construction of energy objects in cooperation with Russia and as a coup-de-grace for skeptics, an 11.3\% trade growth with the countries joining the BRI are the most valuable positive effects of the initiative. According to the research of The International Financial Forum, countries engaged in the initiative or neighboring with the Silk Road Economic Belt corridors benefit in development from the initiative-their development is faster at $1.5 \%$ to $5.5 \%$ of gross domestic product (GDP) growth per year, which is a noteworthy result. It is difficult to admit, but the EAEU is destined to relinquish to such a mighty adversary unless the strategy of counteraction is developed. As was already mentioned, the EAEU cannot withstand the fight alone. Its logical allies are India and Brazil. In a different geopolitical climate, it could have been the European Union, but currently, this is unlikely. It seems that the EU has lost its drivers and is progressing along a path to self-insufficiency (either from the USA, just as it is today, or from China and its allies, or from both).

\section{Discussion}

As is clearly shown above, the process of development of both BRI and the EAEU faces several problems and concerns. The process of conjugation of these initiatives is moving at a slow pace; it is 
plausible that in the next 5-7 years, the realization of conjugation will only on paper. The entire mechanism of conjugation is driven by the Russian-Chinese partnership because Kazakhstan, one of the new allies of the PRC, is not interested in EAEU conjugation and has shown a propensity to build bilateral relations with China. Other EAEU members do not possess the required power and political influence to cooperate with China as equal or, at least not inferior, partners.

We must determine the most attractive strategies for EAEU and BRI conjugation and propose ways to implement them. The data demonstrated above show that the weak points of EAEU are: The financial resources and lack of planning, slow economy development and the high dependency on the Russian economy. The main downturns in inter-union trade were noticed in the periods of sanction strengthening against Russia. The key problems of BRI are: Lack of adequate institutions, concerns on the Chinese influence on the project, slow growth of non-Chinese investments in the participating countries, high competition from the Chinese companies. In order to solve these problems, a number of recommendations are given hereinafter.

\subsection{Financial Cooperation}

The financial mechanisms existing in the EAEU are relatively weak and can be effective only inside the integration. However, many measures that were undertaken to protect the financial system of Russia and, consequently, the EAEU from sanctions proved to be effective within the scale of the EAEU. Investment partnership is one of the most important elements in the context of international relations. In 2018, China issued a credit of $\$ 10$ billion to Vnesheconombank for deeper EAEU integration and its development (Suokas 2018).

The next crucial step is increasing the partnership between the Eurasian Development Bank (EDB), Silk Road Fund and Asian Infrastructure Investment Bank (AIIB). Today, these financial institutions function separately; their cooperation can bring many benefits to all the participants, particularly in the sphere of cutting financial transaction expenditures. The implementation of infrastructural projects within the EAEU is much easier with participation of the EDB as a budgeting and controlling mechanism. Moreover, such actions will provide grounds for further development of the Bank and improve its international rankings. However, Chinese authorities still treat the EAEU not as an equal partnership between states, but as a mechanism constructed by and for Russia (not without reasons, but such attitude is a covert attack on the whole of the EAEU because of undergirding inter-EAEU conflicts and reciprocal insults), and this is why the main affairs concerning the EAEU are conducted via Russian banks.

Mir, the Russian national payment system, is widely used in the EAEU. China Union Pay is widely used in China and its neighboring countries. The operators reached a key agreement to produce cards connected to both of the systems. However, this practice is not widely spread. In order to promote it, it is essential to adapt stimulating measures, for instance, to provide a higher cashback for customers in Chinese, Russian and other shops (including internet trade) and lower or no commission for partner banks.

Close and productive cooperation with the New Development Bank (NDB) of BRICS is crucial to involve Brazil and India in order balance the Chinese power in the BRI. In case the named countries are not tightly involved in the project and multilateral dialog, including Russia and China, the whole idea of conjugation will make no sense because of the inferior position of the EAEU economies (not supported in this scenario by India and Brazil) compared with China and the economies of South-East Asian countries. Cooperation between ABII and NDB exists currently, but its effectiveness is low as the majority of projects of BRI are controlled and budgeted by Chinese banks, and other international financial organizations do not participate. It looks like China has intently created a financial monopoly within the territory of the BRI, which is why it is vital either to introduce other competitive financial mechanisms into the region or develop a new strand of international law concerning the counteracting of the monopoly among supranational organizations. The latter seems close to impossible, but the demand for this type of jurisprudential science has increased in the last five years. 
Still, it should be remembered that by creating a system of deterring Chinese expansion, Russia and its partners cannot make the mistake of surrounding China by barriers and walls. The one who pays gets the benefits. Today, China pays.

All the mentioned measures will contribute to higher effects of conjugation, both positive and dubious.

\subsection{Unifying Trade Practices and Removing Trade Barriers}

As was already mentioned before, Chinese partners often do not want to invest in the EAEU because of the differences in trade practices. It is clear that the market of the EAEU is attractive to both investors and exporters. The significant quantity of natural resources, high potential of development in a number of spheres and the relatively high percentage of rich and ultra-rich citizens make long-term trade and financial relations lucrative; however, there are numerous risks.

First and foremost, EAEU authorities are reasonably skeptical about cooperation with Chinese companies based on the conditions offered to other partners. It is clear that the construction of a railroad in the EAEU by Chinese workers and using Chinese raw materials is unsustainable. EAEU countries see themselves as equal partners and do not need Chinese capital (at least, according to their official position) as much as Central Asian nations do. In order to solve this problem, a new approach to partners is required from China. The EAEU is not just another part of the BRI, it is a powerful player in the region, and it needs to be treated as such.

China began to promote the idea of a "shared future for mankind" (Hu 2012), which is dangerous for the EAEU, at the 18th National Congress of the Communist Party of China. It implies the proliferation of a Chinese way of life and traditions, including economic practices, in countries that joined the BRI. The EAEU cannot support this idea if it wants to preserve unity and has to promote alternatives and support exports of institutes from its members in Central Asia and South-East Asia. The development of EAEU institutes is very slow (Figure 2); therefore, structural reform of the legislative system and the system of state governing is badly needed in order to return to the tempo of changes in 2008-2014.

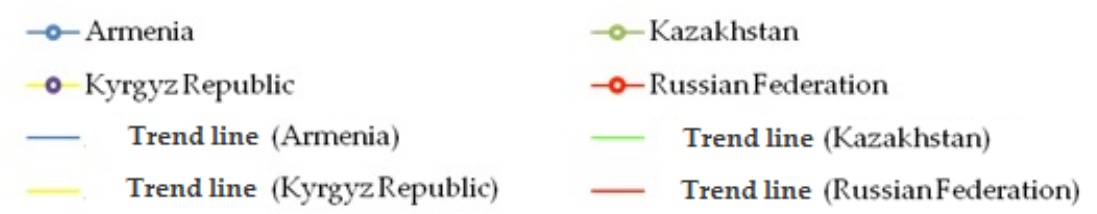

$0-$

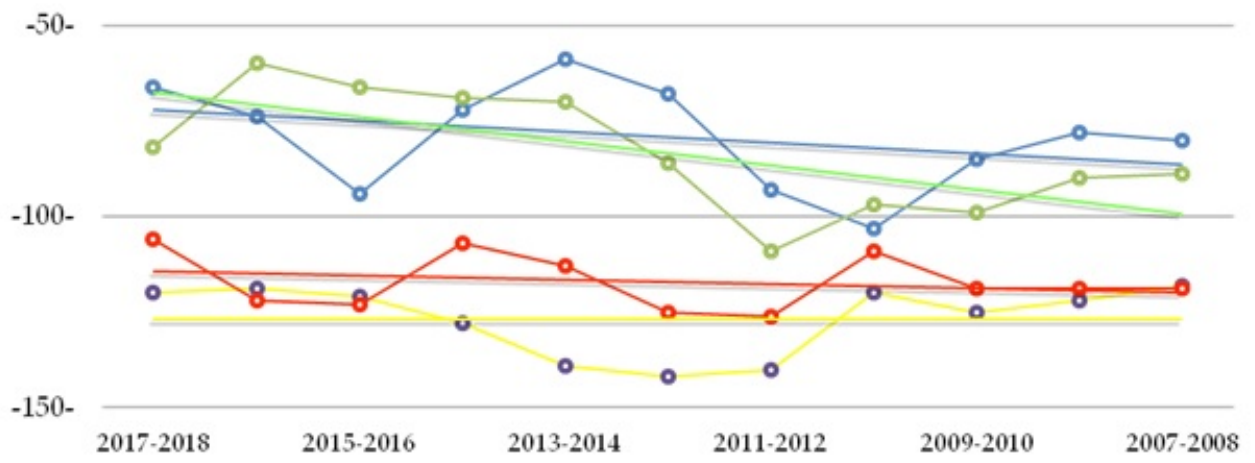

Figure 2. Dynamics of institutional development of EAEU countries. Source: Created by authors, based on the World Economic Forum Annual reports (WEF 2019). 
To sum up, the conjugation of European and Western economic practices seems a difficult task, with lots of disruption arising around it. The first moves toward the implementation of this plan have been taken by China, and some of them make a reliable basis for future cooperation, for example, China is planning to establish an international tribunal for commercial cases (Li 2017). Despite the arising issues, such as what law would be used by the planned Chinese institution, in the long-run, the idea of conjugating, standardizing and harmonization of legislative systems should be considered as the main task of multicultural dialog between the EAEU and Western countries. The first step is an open and constructive cultural dialog between Russia and China, which does exist today. Spreading a tolerant and respectful attitude toward each other's culture is the main task for both countries.

Removing trade barriers is not an easy nor quick task. According to Balassa integration stages, the EAEU is on the third stage of integration, so it seems reasonable to expand Eurasian integration in accordance with V. Putin's idea of Big Eurasia and create a number of free trade zones, possibly even with China, in order to eliminate trade barriers.

\subsection{Tight Cooperation on the Energy Markets}

Both EAEU and BRI states are mighty players in the energy market. The first are producers, while the latter are mostly consumers. It is clear that Russia is one of the main exporters of oil and gas to Asia. Consequently, it promotes the idea of constructing new infrastructure and new pipelines with a higher carrying capacity. It requires a tremendous inflow of investment, the biggest part of which is to be harnessed in an exclusive market of Russian oligopolistic oil companies with public ownership. China, in turn, supports the idea as its leaders of the industry are ready to provide capital resources. Chinese intentions are motivated by the growing demand for hydrocarbons on PRC national market. Today the rate of growth of demand is falling, but still stays high.

Constructing the transit infrastructure is a matter of time, but $\mathrm{Xi}$ Jinping is grasped by the idea of creating a single institution under the BRI that will regulate the relations between member countries in the energy sphere. Despite the fact that the Russian Federation and the EAEU strongly cooperate in terms of energy because of benefits of transit fees and lower prices on gas and crude oil that could be potentially realized if the project succeeds, they will not support the Chinese goal. Russia is concerned by the prospect of losing the monopoly on energy exports and the growing risks of the disintegration of the EAEU.

The preferred path to conjugation in terms of energy is successively increasing export to Asia and diversifying partners, which requires new types of oil and gas products, such as a compressed natural gas, which is in high demand in Japan. In addition, the second step required is setting new export channels, including maritime exports via tankers. This will boost the development of the infrastructure of ports in the northern regions of Russia and in the Caspian region. The first would evolve in modernizing the Northern Sea Route and offering more benefits to BRI countries, which intend to export goods to Europe via the Northern Corridor that is actively discussed in the talks concerning using the resources of the Arctic Ocean. Moreover, this plan adds to the revenues that the EAEU can receive from the BRI; it is the fastest route and it allows the use of big cargo vessels, extending the volumes of transported goods. It bears its own risks, but the introduction of this corridor lies in the sphere of interests of both Russia and China, so it looks like the number of corridors of the BRI will be extended in the near future.

The Steppe Route through Mongolia is another interesting and prospective alternative. In addition to exporting electric energy to Mongolia, the EAEU can cut down on the expenses of transporting goods from South-East Asia via Urumqi (current variant) by decreasing the length of the route by at least $1500 \mathrm{~km}$.

Promoting these ideas in the sphere of energy conjugation along with the reluctance to accept the idea of one regulator under the BRI is the key to the successful and prosperous future of the EAEU and Russia. 


\subsection{Eliminating Political Tensions in Asia Step-by-Step by Non-Violent Measures and Multilateral Talks}

Asia is a hotbed of political tensions. The reasons for this lie in the rich and bloody past of the region. The most reasonable approach to settling tensions is by conducting multilateral talks. However, some countries stick to the opinion that sanctions and exposure to military force can bring peace to this complex region. Such an attitude is unacceptable. The process of conjugation of EAEU and BRI is based on peaceful and non-violent cooperation. Disseminating the ideas of settling conflicts by diplomatic, not military measures is the main goal of both organizations.

Russia and China are actively appealing to the United Nations mechanism to soothe the discrepancies between the countries. However, lately, the PRC is leading active (passive-aggressive, citing American and European mass media) policy in the South-China Sea and in a number of economic conflicts with South Korea and Vietnam. It took this course because of two reasons: Firstly, it felt the power to act this way because of extensively growing military and economic power (so-called "success dizziness"), and secondly, economic rivalry with the USA and its allies forced China to act in a more authoritative way. Despite these reasons, the proliferation and deepening of such behavior is worrying.

Further measures for conjugation are to be undertaken only in the case that the PRC does not start conducting harsher policy in the region because the apprehensions of the EAEU with regard to the increasing power of China will be upheld by such policy.

\subsection{Cooperation in the Sphere of Human Development and Ecology}

Both the BRI and EAEU have high expectations of human development and social partnership. It is worth mentioning that Chinese universities were in the top 100 best universities in 2018 (U. S. News 2019), and there were also EAEU universities on the list. China and India have gained a lot from the Soviet education system and human capital development, just as the EAEU inherited many institutes from the USSR. Further partnership in this sphere along with partnership in tourism and scientific research are the first signs of a deeper partnership.

Ecology is an important question in the process of conjugation. Putting aside political and economic yearning, BRI countries are less developed in this sphere than those of the EAEU. Solving environmental issues in China (coal smog over Beijing and other industrial centers, low environmental standards of national companies, etc.), India (poverty causing the lack of care for natural resources) and the Indian and the Pacific Ocean (marine debris and other pollution) by working together is another global task for future generations that can be solved using intermediary institutions that are to be created during conjugation. When reaching that goal, it will be much easier to eliminate non-tariff barriers, such as sanitary control and other similar measures. It would be fruitful for EAEU to create such an organization under its brand, but creating it under the BRI brand is acceptable too.

\section{Conclusions}

The idea of the conjugation of the EAEU and BRI is one of the most ambitious initiatives in Asia. It will bring benefits to all the participants, but it is nearly impossible to say for sure how the risks that it bears will influence the EAEU as the weaker party. In order to preserve the unity of the union, Russia has to stick to the policy above. Otherwise, the chances of the disintegration of the organization are high. The game has big stakes for every player, so careful planning and estimation of effects is essential. Still, EAEU has weak drivers for growth, so it cannot afford to lose time. It was proved that both EAEU and BRI are effective instruments for developing the Asian region. The statistical data given allow several projections of the future of BRI and EAEU and the possibilities arising from the conjugation idea to be made.

Conjugation is a difficult process that does not possess concrete stages; therefore, according to the authors' opinion, conjugation can be recognized as successful when: I stage-the BRI functions as it is planned to and when at least one of the corridors goes through the EAEU; II stage-the EAEU and BRI 
have trade agreements, particularly free-trade agreements with each other's member states or between organizations; III stage-partnership in matters of security and monetary policy (not a single currency, but preferential currency agreements and payments in national currencies).

The best guess for the time when the conjugation process realizes each of these stages according to current dynamics is as follows: I stage by 2025, II and III stages are difficult to approximate, but should be no later than 2040-2050. Such approximations are made according to the fact that 2015 was the year when the conjugation process first began; in 2018, it reached an important milestone-the principal agreement on main matters. The EAEU has existed for eight years, and the free-trade zone agreement was reached within five years; therefore, this tempo gives a basis for supposing that by 2025 all the natters of free-trade zone will be settled, and the strategy will be developed.

The hypothesis stated and proven above offers some basic recommendations for the EAEU and BRI in order to maximize the conjugation effects.

1. The EAEU does not want to be an inferior partner, but according to trade and macroeconomic statistics, its members cannot be compared with China, or to a lesser extent, with India. The EAEU countries are weaker, matching members of the BRI, so their politics should be aimed at balancing, not fighting Asian powers, and finding a compromise with them. Citing Deng Xiaoping, the China and Russia partnership will not be dangerous if Russia is strong. Therefore, the main aim of domestic policies of EAEU countries should be comprehensive development and building competitive economies.

2. The EAEU still has the political power to make its opinion count; therefore, involving other international organizations in the BRI is a good idea. At the same time, the more platforms for discussion there are in the BRI, the better this is for the EAEU. Strategically, the EAEU should form a block of allies inside the BRI, not to slow the initiative down but to form a healthy opposition to pro-Chinese countries.

3. Today, the relations between Russia and China are stable and nearly halcyon. The main reason for this is their mutual opposition to pro-American forces in Asia. Moreover, the behavior of the American establishment pushes Russia and China closer together. Kissinger warned Western countries against such steps because such partnership threatens Western dominance in the world. It seems that nobody heeded this warning. At the same time, Russia cannot be an ally, just a partner to China. The PRC conducts a Sinocentricpolicy that irritates and concerns its partners, it does not regard its partners as equals except for rare exclusions and does not take into account their interests unless their power is greater than that of the Chinese. That is why Russia, in positioning itself as a superpower, cannot ally with China.

In order to achieve the goals of effective development, the BRI should:

1. Pursue the goals of attracting FDI to less developed countries in the region in order to create a strong and transparent economic bloc. In the case that the Chinese policy remains the same, the triangle of Russia-China-India will be separated into either binational coalitions on strategic questions or the partnership will fail to achieve the development goals.

2. Tend to avoid open confrontation on the global markets with the key players and build an interconnected regional market in order to form a coalition of partners, connected by trade, investments and development strategies. In order to achieve this, conjugation with the EAEU is needed, but the EAEU itself should be strong enough to overcome the economic stresses caused by the conjugation with a mightier partner.

3. Provide a clear strategy and avoid representing China as a senior partner because it does not attract EAEU countries to the initiative but only forces them to participate in order to survive, making them unreliable partners.

All of the above-mentioned factors do not mean conjugation is a temporary tendency that began due to pressure from Europe and the USA. It is a logical development of Russian and EAEU policy in 
Asia in the 21st century. The efficiency of conjugation is hard to assess directly, but on the basis of the given data, the authors expect that at this stage of economic development of the EAEU countries and the institutional development of the BRI, the conjugation process will be an effective and beneficial decision for both sides.

Author Contributions: Conceptualization, E.M. and I.P.; methodology, I.P. and O.S.; data collection, E.T., K.S. and S.P.; analysis of results, all the authors; writing—original draft preparation, K.S. and S.P.; writing-review and editing, E.M., E.T. and O.S.; supervision, I.P.

Funding: This research received no external funding.

Conflicts of Interest: The authors declare no conflict of interest.

\section{References}

AIIB. 2019. 2018 AIIB Annual Report and Financials. Available online: https://www.aiib.org/en/news-events/ annual-report/2018/home/index.html (accessed on 5 October 2019).

Ansar, Atif, Bent Flyvbjerg, Alexander Budzier, and Daniel Lunn. 2016. Does infrastructure investment lead to economic growth or economic fragility? Evidence from China. Oxford Review of Economic Policy 32: 360-90. [CrossRef]

Belt and Road Portal. 2018. Action Plan on Belt and Road Standard Connectivity (2018-20). Available online: https://www.yidaiyilu.gov.cn/zchj/qwfb/43480.htm (accessed on 2 March 2019).

Campbell, Kurt M., and Ely Ratner. 2018. The China Reckoning: How Beijing Defied American Expectations. Foreign Affairs 97: 60-70. Available online: https://www.foreignaffairs.com/articles/china/2018-02-13/chinareckoning (accessed on 2 March 2019).

Chzhao, Yu. 2015. On Conception of “Economic Zone of the Silk Route". Post-Soviet Mainland 1: 18-28.

Czerewacz-Filipowicz, Katarzyna. 2017. Economic and Geoeconomic Effects of the Eurasian Economic Union: Trade Aspects. In Country Experiences in Economic Development, Management and Entrepreneurship. Edited by Mehmet Huseyin Bilgin, Hakan Danis, Ender Demir and Ugur Can. New York: Springer International Publishing, pp. 331-33. [CrossRef]

Djankov, Simeon, and Sean Miner, eds. 2016. China's Belt and Road Initiative: Motives, Scope, and Challenges. Washington: Peterson Institute for International Economics, Available online: https://piie.com/system/files/ documents/piieb16-2_1.pdf (accessed on 2 March 2019).

EEC. 2019. Foreign Trade with Third Countries. Available online: http://www.eurasiancommission.org/ru/act/ integr_i_makroec/dep_stat/tradestat/tables/extra/Pages/default.aspx (accessed on 2 March 2019).

EEC Portal. 2019. Portal of General Information Resources and Open Data. Obstacle Registry map. Available online: https://barriers.eaeunion.org/en-us/pages/obstacles.aspx (accessed on 17 January 2019).

Eurasian Development Bank. 2019. Eurasian Economic Integration. Report 52. Available online: https://eabr.org/ upload/iblock/211/EDB_Centre_Report_52_Eurasian_Economic_Integration_2019_eng.pdf (accessed on 5 October 2019).

Eurostat. 2019. EU28 Trade by SITC Product Group. Available online: http://appsso.eurostat.ec.europa.eu/nui/ show.do?dataset=ext_st_eu28sitc\&lang=en (accessed on 2 March 2019).

Garbuzarova, Elena G. 2019. Cooperation between the Eurasian Economic Union and the Silk Road Economic Belt: Benefits, Risks, Achievements. Post-Soviet Issues 6: 8-15. [CrossRef]

Glazyev, Sergey. 2017. Battle for Dominance in the XXI Century. Russia - USA - China. Seven Scenarios for the Foreseeable Future. Moscow: Knijniy mir.

$\mathrm{Hu}$, Jintao. 2012. Report of Hu Jintao to the 18th CPC National Congress. Beijing: China Internet Information Center, Available online: http://www.china.org.cn/china/18th_cpc_congress/2012-11/16/content_27137540_11.htm (accessed on 2 March 2019).

Johnston, Lauren A. 2019. The Belt and Road Initiative: What Is in It for China? Asia E the Pacific Policy Studies 6: 40-58. [CrossRef]

Kissinger, Henry. 2012. On China. New York: Penguin Books.

Li, Cheng. 2016. Chinese Politics in the Xi Jinping Era: Reassessing Collective Leadership. Washington: Brookings Institution Press. 
Li, Yang. 2017. China to set up Belt and Road Commercial Court. Belt and Road Portal. Available online: https://eng.yidaiyilu.gov.cn/qwyw/rdxw/29380.htm (accessed on 2 March 2019).

Lim, Tai Wei, Henry Hing Lee Chan, Katherine Hui-Yi Tseng, and Wen Xin Lim. 2016. China's One Belt One Road Initiative. London: Imperial College Press. [CrossRef]

Luzyanin, Sergey. 2016a. Absorption, Conjugation or Conflict? SCO, the Chinese "Silk Road" Project and the EAEU: Options for Interaction in Eurasia. Part I. Institute of Far Eastern Studies of the Russian Academy of Sciences: Available online: http://www.ifes-ras.ru/publications/report/2050-luzyanin-sg-pogloshhenie-sopryazhenieili-konflikt-chast-i (accessed on 2 March 2019).

Luzyanin, Sergey. 2016b. Absorption, Conjugation or Conflict? SCO, the Chinese "Silk Road" Project and the EAEU: Options for Interaction in Eurasia. Part II. Institute of Far Eastern Studies of the Russian Academy of Sciences: Available online: http://www.ifes-ras.ru/publications/report/2051-luzyanin-sg-pogloshhenie-sopryazhenieili-konflikt-chast-ii (accessed on 2 March 2019).

MFA of the People's Republic of China. 2017a. Xi Jinping Holds Talks with President Vladimir Putin of Russia The Two Heads of State Agree to Make Joint Efforts to Continuously Deepen China-Russia Comprehensive Strategic Partnership of Coordination. Available online: https://www.fmprc.gov.cn/mfa_eng//wjdt_665385/ wshd_665389/t1475872.shtml (accessed on 2 March 2019).

MFA of the People's Republic of China. 2017b. Xi Jinping Holds Talks with President Nursultan Nazarbayev of Kazakhstan Two Heads of State Agree to Push China-Kazakhstan Comprehensive Strategic Partnership for Sound and Stable Development at Higher Levels. Available online: https://www.fmprc.gov.cn/ mfa_eng/topics_665678/xjpdhjxgsfwbcxshzzcygyslshdsqchyhastnzxsbhkms/t1469516.shtml (accessed on 2 March 2019).

Miller, Tom. 2017. China's Asian Dream: Empire Building along the New Silk Road. London: Zed Books Ltd.

Mingfu, Liu. 2015. The China Dream: Great Power Thinking and Strategic Posture in the Post-American Era. New York: CN Times Books.

OECD. 2018. Economic Outlook for Southeast Asia, China and India 2019. Towards Smart Urban Transportation. Available online: https://www.oecd.org/development/asia-pacific/01_SAEO2019_Overview_WEB.pdf (accessed on 5 October 2019).

Parello-Plesner, Jonas, and Mathieu Duchâtel. 2015. China's Strong Arm: Protecting Citizens and Assets Abroad. London: International Institute for Strategic Studies.

Porter, Michael E. 1990a. The competitive advantage of nations. Harvard Business Review 68: 73-93.

Porter, Michael E. 1990b. Determinants of National Competitive Advantage. In The Competitive Advantage of Nations. New York: Free Press, pp. 69-130. [CrossRef]

Stronski, Paul, and Nicole Ng. 2018. Cooperation and Competition: Russia and China in Central Asia, the Russian Far East, and the Arctic. Washington: Carnegie Endowment for International Peace. Available online: https://carnegieendowment.org/2018/02/28/cooperation-and-competition-russia-and-china-incentral-asia-russian-far-east-and-arctic-pub-75673 (accessed on 2 March 2019).

Suokas, Janne. 2018. China pledges \$10bn to Silk Road, Arctic projects in Russia. GBTIMES. Available online: https://gbtimes.com/china-pledges-10bn-to-silk-road-arctic-projects-in-russia (accessed on 2 March 2019).

U. S. News. 2019. Best Global Universities in China, U.S. News \& World Report. Available online: https://www. usnews.com/education/best-global-universities/search?country=china\&name $=($ accessed on 2 March 2019).

UNCTADstat. 2019. Data Center. Foreign Direct Investment. Available online: http://unctadstat.unctad.org/EN/ (accessed on 2 March 2019).

Vinokurov, Evgeny, and Taras Tsukarev. 2018. The Belt and Road Initiative and the transit countries: An economic assessment of land transport corridors. Area Development and Policy 3: 93-113. [CrossRef]

Wang, Yiwei. 2016. The Belt and Road: What Will China Offer the World in Its Rise. Beijing: New World Press.

WEF. 2019. World Economic Forum. Reports. Available online: https://www.weforum.org/reports?page=2 (accessed on 2 March 2019).

Weiwei, Zhang. 2016. China Horizon: Glory and Dream of a Civilizational State. Singapore: World Century. [CrossRef]

Wink, Marcos Vinício, Jr., Hsia Hua Sheng, and William Eid Junior. 2011. Transaction costs: An empirical analysis of their relationship with investment and foreign direct investment. Revista de Administração de Empresas 51: 175-87. [CrossRef] 
Wolczuk, Kataryna, and Rilka Dragneva. 2017. The Eurasian Economic Union: Deals, Rules and the Exercise of Power. In Chatham House Research Paper. London: Royal Institute of International Affairs. Available online: https://www.chathamhouse.org/sites/default/files/publications/research/2017-05-02-eurasianeconomic-union-dragneva-wolczuk.pdf (accessed on 2 March 2019).

Xinhua. 2013. China, Tajikistan Establish Strategic Partnership. China Daily. May 20. Available online: http://www.chinadaily.com.cn/china/2013-05/20/content_16513300.htm (accessed on 2 March 2019).

Xinhua. 2017. Xi Wraps up State Visit to Laos with Strengthened Partnership. Available online: http://www. xinhuanet.com//english/2017-11/14/c_136752151.htm (accessed on 2 March 2019).

Xinhua. 2018a. China Updates "Sensitive Sectors" for Outbound Investment. Available online: http://www. xinhuanet.com/english/2018-02/11/c_136967702.htm (accessed on 2 March 2019).

Xinhua. 2018b. Survey Shows Economic Potentials for Countries Joining Belt and Road Initiative. Available online: http://www.xinhuanet.com/english/2018-04/19/c_137122158.htm (accessed on 2 March 2019).

Zank, Wolfgang. 2017. The Eurasian Economic Union: A Brittle Road Block on China's “One Belt-One Road"-A Liberal Perspective. Journal of China and International Relations 5: 67-92. [CrossRef]

Zhang, Maggie. 2017. Mind the gap - Standard Chartered steps up with US\$20 billion pledge for Belt and Road projects. South China Morning Post. December 17. Available online: https://www.scmp.com/business/ companies/article/2124657/mind-gap-standard-chartered-steps-us20-billion-pledge-belt-and (accessed on 2 March 2019).

Zhou, Jin. 2018. Forum to Chart Blueprint for BRI Teamwork. China Daily. December 17. Available online: http://global.chinadaily.com.cn/a/201812/17/WS5c16f8e6a3107d4c3a0011bd.html (accessed on 2 March 2019).

(C) 2019 by the authors. Licensee MDPI, Basel, Switzerland. This article is an open access article distributed under the terms and conditions of the Creative Commons Attribution (CC BY) license (http://creativecommons.org/licenses/by/4.0/). 